\title{
Falls and quality of life of people with cataracts
}

\author{
Quedas e qualidade de vida de idosos com catarata
}

Carolline Menezes ${ }^{1}$, Karla Helena Coelho Vilaça², Ruth Losada de Menezes ${ }^{3}$

\begin{abstract}
Objective: To investigate the association between falls and quality of life in elderly individuals with cataract. Methods: This was an observational and cross-sectional study carried out in the Federal District, Brazil, with a sample of 38 community-dwelling elderly individuals, who were divided into two groups: falling elderly $(n=18)$ and non-falling elderly ( $n=20)$. The NEI-VFQ-25 was used as a tool to assess the patient overall health and the quality of life related to visual health. Sample characterization was performed by descriptive analysis and the nonparametric Mann-Whitney test $(p<0.05)$ was used to evaluate the association between falls and the other variables. Results: Elders within the age group $\geq 70$ years old were the majority in this study. 36 participants (94.74\%) of this study claimed to have some vision problems. Falling elderly presented lower scores when compared to the non-falling elderly ( $p=0.0159)$ and they also showed worse mental health $(p=0.0001)$, higher level of dependence $(p=0.0008)$ and greater difficulty to perform up close vision tasks $(p=0.0299)$ and far vision tasks $(p=0.0104)$. Conclusion: Falls have a negative impact on the quality of life of elderly individuals with cataract, which makes preventive actions and the treatment and/or correction of visual impairments important in order to avoid future harms.
\end{abstract}

Keywords: Cataract; Accidental falls; Quality of life; Aged

\section{RESUMO}

Objetivo: Investigar a associação entre quedas e qualidade de vida em idosos com catarata. Métodos: Tratou-se de estudo observacional com delineamento transversal, realizado no Distrito Federal, Brasil, com uma amostra de 38 idosos comunitários divididos em dois grupos: idosos caidores $(\mathrm{n}=18)$ e idosos não caidores $(\mathrm{n}=20)$. Avaliou-se por meio do instrumento National Eye Institute - Visual Function Questionnaire 25 (NEI-VFQ 25) a saúde geral dos indivíduos da amostra, assim como a qualidade de vida relacionada à saúde visual. A caracterização da amostra foi realizada por meio da análise descritiva a fim de avaliar a associação entre quedas e demais variáveis, utilizou-se o teste não paramétrico de Mann-Whitney ( $<<0,05)$. Resultados: A faixa etária $\geq 70$ anos prevaleceu entre os participantes da pesquisa (63,16\%). Dentre os idosos que fizeram parte deste estudo, $36(94,74 \%)$ relataram ter algum problema para enxergar. Idosos caidores apresentaram escore geral mais baixo, quando comparados aos não caidores $(p=0,0159)$, apresentaram também maior dificuldade em realizar atividades para perto $(\mathrm{p}=0,0299)$ e para longe $(\mathrm{p}=0,0104)$, pior saúde mental $(\mathrm{p}=0,0001)$ e nível mais elevado de dependência ( $\mathrm{p}=0,0008)$. Conclusão: As quedas interferem negativamente na qualidade de vida de idosos com catarata, tornando as ações para prevenção de quedas e o tratamento e/ou correção do déficit visual importantes para evitar prejuízos futuros.

Descritores: Catarata; Acidentes por quedas; Qualidade de vida; Idoso

\footnotetext{
1,3 Postgraduate Course, Graduate Program in Health Sciences and Technology, Universidade de Brasília (UnB), Campus Ceilândia, DF, Brasilia, Brazil.

2 Stricto Sensu Postgraduate Program in Gerontology, Universidade Católica de Brasília (UnB), Brasília, DF, Brazil. Institution where the study was conducted: Universidade de Brasília, Campus Ceilândia, Brasília, DF, Brazil.
} The authors declare no conflicts of interests.

Received for publication 16/09/2015 - Accepted for publication 27/10/2015 


\section{INTRODUCTION}

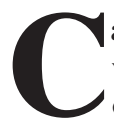
ataract is the leading cause of blindness and reversible visual impairment in the world ${ }^{(1-3)}$, and is defined as any opacity in the crystalline reducing the visual acuity. It affects about $75 \%$ of the elderly over 70 years of age ${ }^{(3-5)}$, and impacts various aspects of vision interfering negatively in the quality of life (QOL) ${ }^{(4,6)}$. According to Lee et al., decreased visual acuity is the second symptom of greater impact in the QOL, second only to breathing difficulties ${ }^{(4)}$.

Consequent to cataract, there is a decrease of visual communication, thus increasing the risk for falls in this population $^{(7,8)}$, because in parallel comes decreased stability, balance, perception of distance and depth, and adaptation to dark, which results in difficulties for the recognition of impending dangers $^{(3,9,10)}$. Elderly in this condition, struggling to remain stable facing complex environments and tasks, have two times more chances to fall ${ }^{(9,11)}$.

The fall is defined as the unintentional displacement of the body to a level lower than the starting position without correction in a timely manner, being determined by multifactorial conditions which compromise the stability, i.e. mechanisms involved with the maintenance of posture ${ }^{(12)}$. It is considered to be an important cause of morbidity and mortality in the elderly population, and one of the leading clinical and public health problems due to the high incidence, the complications and the high healthcare $\operatorname{costs}^{(9,13)}$. This event can result in physical, functional and psychosocial limiting consequences, also resulting in reduced $\mathrm{QOL}^{(4,12-14)}$.

Considering the limiting effect of cataracts and falls imposed on the elderly population, the aim of this study is to assess the association between falls and the quality of life in elderly with cataract.

\section{Methods}

It is an observational study with cross-sectional design conducted in Distrito Federal (DF), Brazil. We assessed 55 elderly patients from the ophthalmology departments of two public hospitals in DF enabled for cataract treatment and surgery.

The inclusion criteria used in the present study were: community elderly (e" 60 years) of both sexes with diagnosis of bilateral cataract confirmed by ophthalmic and diagnostic exams. The exclusion criteria were: clinical diagnosis or severe cognitive impairment suggestive of dementia $(M M S E<17)(n=0)$, positive self-report to other uncorrected vision problems $(\mathrm{n}=17)$ and surgical correction of cataract in one eye $(n=0)$. These criteria were adopted to prevent interfering in the interviews and acting as disturbers for the outcome analyzed.

This study was conducted during the period from December 2011 to December 2012.

The research project was approved by the Ethics Committee of the College of Education and Research in Health Sciences (FEPECS), and duly registered with the National Research Ethics Committee (opinion No. 0153/11).

A total of 38 elderly from the 55 previously selected were included in the study and divided into two groups: faller elderly $(\mathrm{n}=18)$ and non-faller elderly $(\mathrm{n}=20)$. It is understood by fallers elderly who have experienced one or more falls in the 12 months preceding the interview.

The questionnaire National Eye Institute - Visual Function Questionnaire 25 (NEI VFQ-25) was applied to assess the overall health of the patient as well as the quality of life related to visual health. This instrument is statistically proven for validity and reliability ${ }^{(15)}$.

The NEI-VFQ 25 consists of three parts, the first with four questions related to general health and vision, the second part with twelve questions about the difficulties with daily activities, and the third part with nine questions related to visual problems and how they can interfere with the activities ${ }^{(15)}$.

The 25 questions contained in the instrument can be grouped into five domains (physical, psychological, level of dependence, social relationships and overall health) and 12 subdomains (general health, vision, eye pain, nearsight activities, farsight activities, social aspects, mental health, activities of daily life, dependence, ability to drive cars, color vision and peripheral vision). For each question, there are 5 or 6 answer alternatives, and for such answers the score ranges from 0 to 100 points $(0,25$, $50,75,100)$. For the questions with 6 possible answers, if the respondent chooses the last option, number 6 , this question will not be scored and will not be part of the score as it does not refer to visual impairment. The total score will have a minimum value of zero and a maximum value of 100 . The higher the score achieved, the better the quality of life and the visual function of the respondant ${ }^{(15)}$.

We collected the following sociodemographic data by semistructured interview: sex, age (years), race (white, black or mulatto / mestizo / brown), education (literacy), marital status (married / living together, single, divorced / separated or widow), socioeconomic activity (with the question: "do you currently work?), economic situation (retirement) and family support (with the questions: 'do you live aline?' and if not 'who lives with you, family or friends?).

On general health data, the elderly were asked and answered a self-report with the number of diagnosed diseases, the number of medications in use, physical activity and self awareness of the ability to see even with the use of glasses or contact lenses (without difficulty, with a little or a lot of difficulty).

The fall was questioned by the question: "have you fallen in the last year?" and if so, "how many times did you fall?"

All patients were told about the objectives and the methodology employed by signing, after said guidance, the term of free consent.

The Mini Mental State Examination was used in the study to exclude the elderly with severe cognitive impairment suggestive of dementia (cutoff $<17$ points) ${ }^{(16)}$. The instrument was developed by Folstein et al. ${ }^{(17)}$, and comprised 30 questions grouped into seven categories: time orientation ( 5 points), spatial orientation ( 5 points), recording three words ( 3 points), attention and calculation ( 5 points), recall of three words ( 3 points), language (8 points) and visual constructive capacity (1 point). For each question 0 (wrong) and 1 (right) is scored, accounting a total score varying from a minimum of 0 points and a maximum of 30 points $^{(18)}$.

After tabulation and use of the data obtained in this study, we chose to characterize the sample and general health data through descriptive analysis and assess the association between falls and other variables using the nonparametric Mann-Whitney test. The statistical program used was BioEstat version 5.3, installed in a Windows environment and with a $\alpha=0.05$ established. 


\section{RESULTS}

The sample included 38 elderly of both sexes, with an average age of 71.66 years $( \pm 5.80)$. Table 1 presents the general characterization of the sample $(n=38)$ according to the variables studied.

\section{Table 1}

\section{General characteristics}

\begin{tabular}{|c|c|c|c|c|}
\hline \multirow[t]{2}{*}{ Caracteristics / Category } & \multicolumn{2}{|c|}{ Fallers $(n=18)$} & \multicolumn{2}{|c|}{ Non- fallers $(n=20)$} \\
\hline & $\mathbf{n}$ & $\%$ & n & $\%$ \\
\hline \multicolumn{5}{|l|}{ Sex } \\
\hline Female & 13 & 34.21 & 7 & 18.42 \\
\hline Male & 5 & 13.16 & 13 & 34.21 \\
\hline \multicolumn{5}{|l|}{ Age group } \\
\hline 60 a 69 anos & 8 & 21.05 & 6 & 15.79 \\
\hline$\geq 70$ anos & 10 & 26.32 & 14 & 36.84 \\
\hline \multicolumn{5}{|l|}{ Color } \\
\hline White & 10 & 26.32 & 6 & 15.79 \\
\hline Black & 4 & 10.53 & 4 & 10.53 \\
\hline Mulatto/Mestizo & & & & \\
\hline /Brown & 4 & 10.53 & 10 & 26.32 \\
\hline \multicolumn{5}{|l|}{ Literacy } \\
\hline Yes & 13 & 34.21 & 13 & 34.21 \\
\hline No & 5 & 13.16 & 7 & 18.42 \\
\hline \multicolumn{5}{|l|}{ Marital status } \\
\hline Married & 6 & 15.79 & 11 & 28.95 \\
\hline Single & 4 & 10.53 & 2 & 5.26 \\
\hline Divorced & & & & \\
\hline /Separated & 2 & 5.26 & 3 & 7.89 \\
\hline Widow & 6 & 15.79 & 4 & 10.53 \\
\hline \multicolumn{5}{|l|}{ Currently working } \\
\hline Yes & 2 & 5.26 & 3 & 7.89 \\
\hline No & 16 & 42.11 & 17 & 44.74 \\
\hline \multicolumn{5}{|l|}{ Retired } \\
\hline Yes & 12 & 31.58 & 15 & 39.47 \\
\hline No & 6 & 15.79 & 5 & 13.16 \\
\hline \multicolumn{5}{|l|}{ Pensioner } \\
\hline Yes & 4 & 10.53 & 3 & 7.89 \\
\hline No & 14 & 36.84 & 17 & 44.74 \\
\hline \multicolumn{5}{|l|}{ Lives alone } \\
\hline Yes & 4 & 10.53 & 1 & 2,63 \\
\hline No & 14 & 36.84 & 19 & 50.00 \\
\hline \multicolumn{5}{|l|}{ Needs caregiver } \\
\hline Yes & 15 & 39.47 & 18 & 47.37 \\
\hline No & 3 & 7.89 & 2 & 5.26 \\
\hline Total & 18 & 47.37 & 20 & 52.63 \\
\hline
\end{tabular}

Regarding the general health and the number of diseases diagnosed, 7 (18.42\%) reported hearing problems, 13 (34.21\%), heart problems, $23(60.53 \%)$ hypertension, $2(5.26 \%)$ embolism / stroke, 8 (21.05\%) diabetes, 3 (7.89\%) tumor / cancer, 13 (34.21\%) arthritis / rheumatism, 4 (10.53\%) chronic lung disease, $5(13,16 \%)$ depression 7 (18.42\%), osteoporosis, 17 (44.74\%) urinary incontinence, 1 (2.63\%), fecal incontinence and 11 $(28.95 \%)$ labyrinthitis.

According to the perception of the elderly participanting in this study, $2(5.26 \%)$ reported having no problem to see, 16
(42.11\%) had little problems and $20(52.63 \%)$ with many problems. For the ability to hear, 17 (44.74\%) reported having no problems, 15 $(39.47 \%)$ had little problems and $6(15.79 \%)$ with many problems.

In relation to the number of medications in use, $7(18.42 \%)$ reported not to make use, $11(28.95 \%)$ to make use of 1 to 2,13 (34.21\%) from 3 to 5 medications, and 7 (18.42\%) used more than 5 .

As for physical activities, 14 (36.84\%) practice them and 24 $(63.16 \%)$ do not practice.

Of the 38 elderly assessed, 18 were from the fallers group $(47.37 \%)$ and 20 from the non-fallers group (52.63\%). Among the faller elderly, $13(72.20 \%)$ were female and $5(27.80 \%)$ male, 6 $(33.33 \%)$ reported having fallen only once, $3(16.67 \%)$ reported two falls, and $9(50 \%)$ three or more falls in the last 12 months. The average age was 71.66 years $( \pm 5.80)$, ranging from 63 to 83 years. The age group of 70 years or more prevailed in both groups, being $10(55.60 \%)$ among the fallers and $14(70 \%)$ among the non-fallers.

The quality of life related to visual health (NEI-VFQ 25) is described by means of general average scores per group, detailed in table 2.

When we compare the group of fallers to the non-fallers, 10 subdomains showed lower scores among the fallers. Of these, besides the general score, four more subdomains assessed by the NEIVFQ 25 showed statistical significance: nearsight activities $(\mathrm{p}=$ 0.0299), farsight activities $(\mathrm{p}=0.0104)$, mental health $(\mathrm{p}=0.0001)$ and dependence $(\mathrm{p}=0.0008)$.

Only $3(7.89 \%)$ participants in the study answered questions relating to the subdomain ability to drive; the others reported not performing this activity. Therefore, these data were not statistically significant for this study, and thus were not presented in the table 2.

Table 2

Comparative analysis of the general average score and subdomains of NEI-VFQ 25 between faller and non-faller elderly

\begin{tabular}{lccl}
\hline \multicolumn{1}{c}{ General score } \\
and subdomains & $\begin{array}{c}\text { Fallers } \\
(\mathbf{n = 1 8}) \\
\text { Average } \\
\text { (Standard deviation) }\end{array}$ & $\begin{array}{c}\text { Non fallers } \\
(\mathbf{n = 2 0}) \\
\text { Average }\end{array}$ & P value \\
\hline General score & $45.79( \pm 20.90)$ & $62.90( \pm 20.47)$ & $0.0159^{*}$ \\
General health & $31.94( \pm 16.73)$ & $31.35( \pm 26.75)$ & 0.6716 \\
Vision & $24.44( \pm 8.56)$ & $31.00( \pm 12.10)$ & 0.1285 \\
Ocular pain & $51.39( \pm 38.24)$ & $66.25( \pm 33.76)$ & 0.0919 \\
Nearsight & & & \\
activities & $42.79( \pm 33.33)$ & $57.20( \pm 35.37)$ & $0.0299^{*}$ \\
Farsight & & & \\
activities & $45.50( \pm 35.24)$ & $62.50( \pm 30.44)$ & $0.0104^{*}$ \\
Social aspects & $67.86( \pm 35.65)$ & $80.00( \pm 28.98)$ & 0.2200 \\
Mental health & $39.44( \pm 39.79)$ & $65.63( \pm 35.44)$ & $0.0001^{*}$ \\
$\begin{array}{l}\text { Daily life } \\
\text { activities }\end{array}$ & $34.03( \pm 36.91)$ & $45.00( \pm 37.64)$ & 0.1917 \\
Dependence & $43.52( \pm 43.76)$ & $71.67( \pm 33.97)$ & $0.0008^{*}$ \\
Color vision & $73.61( \pm 30.28)$ & $88.75( \pm 18.98)$ & 0.1285 \\
Peripheral vision & $61.11( \pm 31.18)$ & $73.75( \pm 27.48)$ & 0.2195 \\
\hline
\end{tabular}

The subdomain "Ability to Drive" was not presented in this table for not presenting statistical significance for this study. (*p $<0.05$ MannWhitney test) 


\section{DiscussiOn}

The assessment of QOL is widely accepted to examine the effects of various diseases and their treatments, including visual problems. The effects of visual system diseases on the quality of life present a growing interest, and since 2001 studies in Brazil make use of the NEI-VFQ 25 for this purpose, since it addresses not only the visual issue but also its influence on several other aspects of the QOL in addition to being a instrument for easy application.

In the group studied, it was possible to observe that both the general and the subdomain scores were mostly from medium to low, which coincides with the results found in other studies $^{(2,15,19,20)}$ indicating that the decreased visual acuity interferes negatively on the QOL.

Visual impairments affect the activities and social participation of elderly, since they generate less visual communication, dependence and mobility restrictions ${ }^{(7,21)}$. Elderly who suffered falls had shown to be even more dependent when compared to those who did not fall. The dependence as a result of adverse events in the later stages of life, as in old age, becomes even more relevant ${ }^{(22)}$. Studies ${ }^{(23,24)}$ associating visual deficits to falls indicate that this adverse event may interfere with functional capacity of the elderly, making it difficult to carry out their basic and instrumental daily-life activities, and affecting directly the quality of life of this population ${ }^{(25)}$.

Another relevant factor noted was the mental health impairment, especially in faller elderly. The fact of becoming dependent makes the elderly often feel undervalued, and it may result in the development of psychological problems and poor quality of life ${ }^{(26,27)}$. As well as the decrease in selfconfidence, low self-esteem and fear of falling triggered after the falls are feelings that guide the elderly after the accident ${ }^{(28)}$. The fear of falling and the falls are common syndromes with potentially serious outcomes among the elderly ${ }^{(29)}$.

Surgical treatment of cataract has a positive impact on the quality of vision, allowing patients and perform well their usual $^{(30)}$ and work ${ }^{(31)}$ activities, and reducing the occurrence of falls, especially after surgery of the first eye ${ }^{(32,33)}$. Educational interventions for eye care for causes and treatment of senile cataract should be encouraged, since patients with underprivileged socio-cultural origin may have misconceptions of the real benefits of the intervention ${ }^{(34)}$.

The presence of depressive aspects is common in elderly with visual impairment caused by cataract, and the improvement of these emotional changes is also seen with the implement of the view after surgery ${ }^{(21,33)}$.

Thus, we see that aspects of HRQOL can be negatively impacted by the fall, what makes us study and understand the importance of preventing this event especially in this population already exposed by visual deficit.

These findings must be understood within the limitations of this study, which apart from being a small sample, did not compare people of similar age group without visual changes. The continuation of this study is recommended, increasing the population studied and drawing other correlations of variables that may influence the HRQOL.

\section{Conclusion}

The data from this study indicate that the HRQOL of the elderly with cataract and who suffered falls is worse, being closely linked to the visual function and mainly to mental health issues and dependence to conduct various activities. Although the results of this study can not be extrapolated to the general population because of the characteristics of the sample, the data analyzed here relate cataracts and falls as two important factors for the worsening of QOL, making the development of strategies for fall prevention and treatment and/or correction of visual impairment imposed by cataracts important to avoid future functional and psychosocial losses.

\section{ACKNOWLEDGEMENTS}

Brazilian National Council of Scientific and Technological Development (CNPq). Public notice MCT/CNPq - Faixa A Number 480434/2011-5; Research Support to New Teachers: Deanship of Research and Postgraduate (DPP/UnB) - Public notice 10/2011.

\section{ReFERENCES}

1. Yamada M, Mizuno Y, Miyake Y. A multicenter study on the health-related quality of life of cataract patients: baseline data. Jpn J Ophthalmol. 2009;53(5): 470-6.

2. Chatziralli IP, Sergentanis TN, Peponis VG, Papazisis LE, Moschos MM. Risk factors for poor vision-related quality of life among cataract patients. Evaluation of baseline data. Graefes Arch Clin Exp Ophthalmol. 2013; 251(3):783-9.

3. Meuleners LB, Fraser ML, Ng J, Morlet $\mathrm{N}$. The impact of first and second eye cataract surgery on injurious falls that require hospitalisation: awhole population study. Age Ageing. 2014;43(3):341-6.

4. Ferraz EV, Lima CA, Cella W, Arieta CE. Adaptação de questionário de avaliação da qualidade de vida para aplicação em portadores de catarata. Arq Bras Oftalmol. 2002;65(3):293-8.

5. Monestam E, Wachtmeister L. The impact of cataract surgery on low vision patients. Acta Ophthalmol Scand. 1997;75(5):569-76.

6. Bravo Filho VT, Ventura RU, Brandt CT, Sarteschi C Ventura MC. Impacto do déficit visual na qualidade de vida em idosos usuários do sistema único de saúde vivendo no sertão de Pernambuco. Arq Bras Oftalmol. 2012;75(3):161-5.

7. Menezes RL, Bachion MM. Condições visuais autorrelatadas e quedas em idosos institucionalizados. Rev Bras Oftalmol. 2012;71(1):23-7.

8. Macedo BG, Pereira SL, Rocha FL, Castro AB. Association between funcional vision, balance and fear of falling in older adults with cataracts. Rev Bras Geriatr Gerontol. 2012;15(2):265-74.

9. Carvalho MP, Luckow ELT, Peres W, Garcias GL, Siqueira FC. O envelhecimento e seus fatores associados. RBCEH. 2011;8(2):265-71.

10. Fabrício SC, Rodrigues RAP Junior ML. Causas e consequências de quedas de idosos atendidos em hospital público. Rev Saúde Pública. 2004;38(1):93-9.

11. Luiz LC, Rebelatto JR, Coimbra AM, Ricci NA. Associação entre déficit visual e aspectos clínico-funcionais em idosos da comunidade. Rev Bras Fisioter. 2009;13(5):444-50.

12. Gomes EC, Marques AP, Leal MC, Barros BP. Fatores associados ao risco de quedas em idosos institucionalizados: uma revisão integrativa. Ciência \& Saúde Coletiva. 2014;19(8):3543-51. 
13. Almeida LP, Brites MF, Takizawa MG. Quedas em idosos: fatores de risco. RBCEH. 2011;8(3):384-91.

14. Lopes RA, Dias RC. O impacto das quedas na qualidade de vida dos idosos. ConScientiae Saúde. 2010;9(3):504-9.

15. Mello PR, Roma AC, Júnior HV. Análise da qualidade de vida de portadores de uveítes de causas infecciosas e não infecciosas pelo questionário NEI-VFQ-25. Arq Bras Oftalmol. 2008;71(6): $847-54$.

16. Silva SL, Silva VG, Máximo LS, Dias JM, Dias RC. Comparação entre diferentes pontos de corte na classificação do perfil de fragilidade de idosos comunitários. Geriatr Gerontol. 2011;5(3):130-5.

17. Folstein MF, Folstein SE, McHugh PR. "Mini-mental state". A practical method for grading the cognitive state of patients for the clinician. J Psychiatr Res. 1975;12(3):189-98.

18. Kirwan C, Lanigan B, O'Keefe M. Vision-related quality of life assessment using the NEI-VFQ-25 in adolescents and young adults with a history of congenital cataract. J Pediatr Ophthalmol Strabismus. 2012;49(1):26-31.

19. Kurna SA, Altun A, Gencaga T, Akkaya S, Sengor T. Vision related quality of life in patients with keratoconus. J Ophthalmol. 2014:694542.

20. Lord SR, Dayhew J. Visual risk factors for falls in older people. J Am Geriatr Soc. 2001;49(5):508-15.

21. Marback R, Temporini E, Kara Júnior N. Emotional factors prior to cataract surgery. Clinics. 2007;62(4):433-8.

22. Silva A, Almeida GJ, Casilhas RC, Cohen M, Peccin MS, Tufik S, et al. Equilíbrio, coordenação e agilidade de idosos submetidos à prática de exercícios físicos resistidos. Rev Bras Med Esporte. 2008;14(2):88-93.

23. Abdelhafiz AH, Austin CA. Visual factors should be assessed in older people presenting with falls or hip fracture. Age Ageing. 2003;32(1):26-30.

24. Fhon JR, Wehbe SC, Vendruscolo TR, Stackfleth R, Marques S, Rodrigues RA. Accidental falls in the elderly and their relation with functional capacity. Rev Latino-Am Enfermagem. 2012;20(5):927-34.

25. Oliveira F, Silva LM, Muccioli C, Soriano ES, Freitas LL, Belfort Júnior R. Qualidade de vida de pacientes pseudofácicos submetidos à cirurgia de catarata com implante de lente intraocular acomodativa. Arq Bras de Oftalmol. 2004;67(3):469-74.
26. Borges MR, Moreira AK. Influências da prática de atividades físicas na terceira idade: estudo comparativo dos níveis de autonomia para o desempenho nas AVDs e AIVDs entre idosos ativos fisicamente e idosos sedentários. Motriz Rev Educ Fís. 2009;15(3):562-73.

27. Ozcan A, Donat H, Gelecek N, Ozdirenc M, Karadibak D. The relationship between risk factors for falling and the quality of life in older adults. BMC Public Health. 2005;5:90.

28. Harwood RH, Foss AJ, Osborn F, Gregson RM, Zaman A, Masud T. Falls and health status in elderly women following first eye cataract surgery: a randomised controlled trial. $\mathrm{Br} \mathrm{J}$ Ophthalmol. 2005;89(1):53-9.

29. Brannan S, Dewar C, Sen J, Clarke D, Marshall T, Murray PI. A prospective study of the rate of falls before and after cataract surgery. Br J Ophthalmol. 2003;87(5):560-2.

30. Ribeiro JE, Freitas MM, Araújo GS, Rocha TH. Associação entre aspectos depressivos e déficit visual causado por catarata em pacientes idosos. Arq Bras Oftalmol. 2004;67(5):795-9.

31. Kara Junior N, Santhiago MR, Parede TR, Espindola RF, Mazurek MG, Germano R, et al. Influência da correção cirúrgica da catarata na percepção laborativa. Arq Bras Oftalmol. 2010;73(6):491-3.

32. Carvalho EM, Garcês JR, Menezes RL, Silva EC. O olhar e o sentir do idoso no pós-queda. Rev Bras Geriatr Gerontol. 2010;13(1):7-16.

33. Friedman SM, Munoz B, West SK, Rubin GS, Fried LP. Falls and fear of falling: which comes first? A longitudinal prediction model suggests strategies for primary and secondary prevention. J Am Geriatr Soc. 2002;50(8):1329-35.

34. Temporini ER, Kara Junior N, José NK, Holzchuh N. Popular beliefs regarding the treatment of senile cataract. Rev Saúde Pública. 2002;36(3):343-9.

\section{Corresponding author:}

Ruth Losada de Menezes

Postgraduate Program in Health Sciences and Technology, Campus UnB Ceilândia - Centro Metropolitano, conjunto A, lote 01, ZIP Code 72220-900.

Ceilândia, Brasília, Distrito Federal, Brazil

Email: ruthlosada@unb.br 